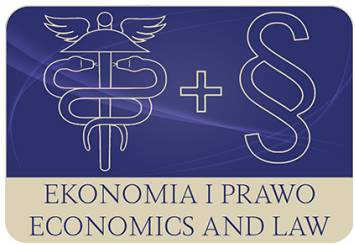

EKONOMIA I PRAWO
EKONOMIA I PRAWO. ECONOMICS AND LAW

Volume 19, Issue 2, June 2020

p-ISSN 1898-2255, e-ISSN 2392-1625

www.economicsandlaw.pl

ORIGINAL ARTICLE

received 17.03.2020; revised 20.04.2020; accepted 30.06.2020

Citation: Piotrowski, D. (2020). Trust in the banking sector in Poland in comparison to global trends.

Ekonomia i Prawo. Economics and Law, 19(2): 319-332. doi:10.12775/EiP.2020.022.

\title{
Trust in the banking sector in Poland in comparison to global trends
}

\author{
DARIUSZ PIOTROWSKI \\ Nicolaus Copernicus University in Torun, Faculty of Economic Sciences and Management, \\ Department of Finance, ul. Gagarina 13a, 87-100 Toruń, Poland \\ darius@umk.pl \\ orcid.org/0000-0001-8482-8064
}

\begin{abstract}
Motivation: Banks are called public trust institutions. This term underlines the importance of trust in the activities of these institutions. The global financial crisis has drastically reduced public trust in banks. However, nowadays, at a time of a global crisis of social trust in broadly understood institutions, more and more people tend to trust banks. This phenomenon has given rise to the need to identify factors for restoring trust in banks. Aim: The aim of the study is to compare changes in the level of trust in banks in Poland with the trends observed in this respect on a global scale. Factors strengthening or weakening public trust in banks will be also identified.

Results: The research shows that in the case of the Polish market, financial stability, improvement of the quality of services provided, and care for security are the factors that have been mainly responsible for the increase in trust in banks in recent years. On a global scale, efficient problem-solving/complaint handling is also an important determinant of high trust in banks. Moreover, cultural factors were identified as determinants of differences in the level of trust in the banking sector in countries of the Western and Eastern civilisations. The research also resulted in demonstrating that the changes in the level of trust recorded for the Polish market were to a large extent a reflection of processes taking place on a global scale. However, a more detailed analysis of the data showed that in the time of the financial crisis in 2009, the decline in the level of trust in banks observed in Poland was stronger than on the global market. In turn, during the period of global economy growth, one year before the outbreak of the COVID-19 pandemic, trust in the banking sector in Poland was at a higher level than the average level of trust in banks recorded on a global scale. Such a considerable dispersion of results stems mainly from factors of an emotional nature.
\end{abstract}


Keywords: trust; ethics; banking sector

JEL: G21; O16; Z13

\section{Introduction}

The functioning of banks is based on trust (Jongchul, 2013, pp. 807-826; Polillo, 2011, pp. 437-464). Trust in these institutions makes a large part of society entrust their savings to them (Gradon, 2015, pp. 61-69). The source of trust in banks, apart from the amount of accumulated capital, lies in the professionalism of the employed staff and conduct in accordance with ethical principles. Bankers use their knowledge of the economic reality and the functioning of financial markets, as well as their analytical capabilities and contacts with entities operating on different markets to ensure the efficient execution of operations ordered by their customers (Lynch, 1991).

However, the history of banking is not only an example of good relations between banks and their customers, but also of bank failures that should be associated with the mismanagement of these institutions. These events resulted in a reduction in public trust in banks in the short term, but in the long term they did not have a major impact on customer relations with banks (Wicker, 2000). This can be linked, on the one hand, to the activities of banks and market supervisors aimed at restoring trust in banks by placing cooperation with customers on a stable, ethical foundation. On the other hand, for many years, customers have generally had no alternative to the financial services provided by banks. The last few decades have seen major changes in this area. The reasons for the reduction in public trust in banks should be seen not so much in the bankruptcies of these institutions as in the financial instability of individual banks or entire financial systems, and in the unethical behaviour of bank managers and employees towards their customers (Cohn et al., 2014, pp. 86-89). The aim of the study is to compare changes in the level of trust in banks in Poland with the trends observed in this respect on a global scale. Factors strengthening or weakening public trust in banks will be also identified.

\section{Literature review}

Since the results of research on trust in banks are the subject of analysis in the present paper, the concept of trust itself should be defined first. Ennew \& Sekhon (2007, pp. 62-68) understand it as 'an individual's willingness to accept vulnerability on the grounds of positive expectations about intentions or behavior of another in a situation characterized by interdependence and risk'. Sztompka (2007, p. 99) defines trust as 'a conviction that the uncertain future actions of other people or the functioning of devices or institutions will be beneficial for us, and actions resulting from that conviction'. On the other hand, Sako (1992, pp. 30-50) defines trust as 'a state of mind, an expectation held by one trading partner about another, that the other behaves or responds 
in a predictable and mutually acceptable manner'. The most complex definition of trust is proposed in a study by Whitener et al. (1998, pp. 513-530): 'first, trust in another party reflects an expectation or belief that the other party will act benevolently. Second, one cannot control or force the other party to fulfill this expectation - that is, trust involves a willingness to be vulnerable and risk that the other party may not fulfill that expectation. Third, trust involves some level of dependency on the other party so that the outcomes of one individual are influenced by the actions of another'.

Trust in banks analysed in the present article refers to individual institutions as well as to the whole banking system. Van Esterik-Plasmeijer \& van Raaij (2017, pp. 97-111) distinguished six determinants of such trust. The first area (competence, ability, expertise) refers to how the persons representing the bank conduct themselves. The second (fairness, credibility, honesty), third (customer orientation, benevolence, concern about customers), and fourth group of determinants (transparency, open and clear communications) are related to the customer-bank (bank staff) relationship. The last two factors: value congruence (shared values) and stability (predictability) factors allow customers to relate to the functioning of banks from a slightly more distant perspective.

Trust in banks in a broad sense can be understood as trust in institutions, and in a narrow sense as trust in their employees. Schumpeter $(1939$, p. 117) points out that to be a banker, it takes "not only highly skilled work, proficiency in which cannot be acquired in any school except that of experience, but also work which requires intellectual and moral qualities not present in all people who take to the banking profession'. In his view, morality in banking is more than just a simple attachment to ethics and a refusal to commit fraud. It seems that today's banks have difficulty meeting these requirements. In the literature on the subject, we hear more and more frequent voices questioning the validity of calling banks institutions of public trust (Dziawgo, 2009, pp. 125-133; Szambelańczyk, 2010, pp. 39-65). According to Dąbrowski (2017, pp. 129148 ), this is because banks have disturbed the equilibrium between profitability and trust. Banks have increasingly begun to resemble companies that base their activities on cost-efficiency at the expense of activities that take into account the criterion of trust that made them a kind of public good. This is not an isolated view. In a global survey of trust in institutions (Edelman, 2013) the opinion that banking and financial services behaviours are common across all business was shared by $63 \%$ of respondents. Polish society is not so critical in its assessment - in a survey conducted in 2013 for the Polish Bank Association (ZBP), 59\% of respondents agreed with the statement that banks are institutions of public trust, while the opposite view was held by $27 \%$ (ZBP, 2013, p. 5).

Criticism of the banks' actions has intensified especially since the global financial crisis initiated in 2007. Banks were accused of loosening the rules of granting loans, basing financing on the money market, rewarding risky actions of their managers, offering financial products not adjusted to customer needs, often of a complex structure and characterised by a significant level 
of risk (Bordo, 2008; Laeven, 2011, pp. 17-40; Lastra \& Wood, 2010, pp. 531550; van Raaij, 2016). Improper practices of banks sometimes resulted in their bankruptcy or state intervention protecting against such a scenario, but more often than not, banks' actions unsettled their financial stability and, in the case of large institutions, were a threat to the security of the entire financial system (Acharya, 2009, pp. 224-255; Haldane \& May, 2011, pp. 351-355). It is worth noting at this point that the beginning of the crisis can be seen in the activities of commercial banks, while the spread of crisis phenomena leading to the erosion of market confidence is largely the responsibility of investment banks (Nishimura, 2010, pp. 25-47; Reynolds \& Newell, 2011). In addition to banks, other institutions can also be held responsible for triggering the global financial crisis. Certainly, market supervisors failed in performing their functions properly. In retrospect, the interest rate decisions taken by FED which, as it turned out, did not serve to stabilise the market situation can also be considered wrong (Goodfriend, 2011, pp. 119-137). The world of politics is also not without blame. This is related to the growing role of economic policy, understood as politicians influencing economic institutions (Dziawgo, 2011, pp. 7-21). This view is confirmed by the results of research conducted by Gangl et al. (2012, pp. 603-614).

\section{Methods}

The aim of the study will be achieved by using a critical analysis of the results of global surveys on the level of public trust in institutions, including financial institutions, published in the Edelman Trust barometer reports in the years 2007-2020. Particular attention will be paid to the determinants of a geographical differences in the level of trust in banks, as well as its variation as per the characteristics of the respondent. These results will be a reference point for the research regarding the Polish market. It will be based mainly on the results of studies of the reputation and image of banks operating in Poland commissioned annually since 2007 by the Polish Bank Association. An attempt will also be made to explain the relatively low level of trust in the Polish banking sector observed in the time of the financial crisis and high level of trust in recent years in comparison to trust in banks on a global scale.

\section{Trust in banks on a global scale}

The data in table 1 show changes in the level of trust in banks on a global scale. These figures were juxtaposed with changes in trust in broadly understood business institutions. The Edelman reports from the years 2007-2011 used in this part of the paper were prepared on the basis of an online (or telephone) survey conducted among the population which was called 'elites' or the 'informed public' meeting the following criteria: age of 25-64, with college education, in the top quarter of household income for each age group in a given country, prolific media users, and involved in business news and public policy. The 
reports for the years 2012-2019 contain data obtained from respondents described as the general population aged $18+$ who were then broke down into groups: the informed public (depending on the year of the survey this group represented $13-17 \%$ of the global population) and mass population (global population not including the informed public).

As the research is always conducted in the period from October to November of the year preceding the year of publication, it actually refers to the opinions of respondents from the year prior to that indicated in each report. Taking the above into account, the author of the present article shows the results as pertaining to the year when the survey was taken and not when the report was published.

In the report from 2007 (Edelman, 2007, p. 11) which contains the opinions of respondents from 2006, i.e. the period of global economic recovery when there were no serious signs of crisis yet, banks enjoyed a very high level of social trust (68\% of respondents trusted these institutions). Only two sectors, 'technology' (75\%) and 'biotech/life science' (71\%), enjoyed greater trust. In the following years, there was a significant drop in trust in banks among the informed public on a global scale to 56\% in 2007 and 45\% in 2008 (Edelman, 2009, p. 15). The drop in trust in banks was much greater than that regarding institutions in the 'business' category. Here the changes in trust levels were negligent, from 52\% in 2006 through $51 \%$ in 2007 to $50 \%$ in 2008 (table 1). This can be interpreted in the following manner: respondents, by significantly lowering the level of trust in a particular sector, indicated who they primarily blamed for the outbreak of the global financial crisis. The drop in the level of trust can also be read as a reduction of the above-average trust which the society had placed in the banking sector in the period preceding the crisis (in 2006) to a level just below the average for business institutions in the first months of the crisis on the financial markets.

A further decline in trust in banks was halted by actions of the following entities: governments (nationalising or recapitalising banks, increasing deposit guarantee amounts), banks (taking over competitors, changing credit policy), central banks (increasing the availability of short-term funding, lowering interest rates, introducing quantitative easing of monetary policy, taking other measures to increase the stability of the financial system), and market supervisors (obliging institutions to disclose toxic assets, increasing capital requirements, or carrying out stress-tests to determine the resilience of banks to possible but unlikely extreme economic conditions) (Langley, 2013, pp. 51-73). The analysis of the data presented in table 1 shows that since 2009 there has been an upward trend in trust in banks (since 2011 - financial services companies). This phenomenon has been fostered by the improvement of the global economic situation. We can also observe a sustained reduction in banks' trust premiums. Since 2008 , trust in banks (financial services sector) has always been below the level of trust in the broadly understood business among the respondents described as the informed public. The data contained in the Edelman (2020) report generally 
represent the views of the general population and cannot therefore be compared with data from earlier years. However, they indicate that within the widest group of respondents in the years 2011-2019, financial services always had the lowest social trust among the analysed sectors of the economy. For example, in 2019 the level of trust for selected sectors of the economy was as follows: technology $-75 \%$, automotive, food and beverage, healthcare $-67 \%$, financial services - 56\% (Edelman, 2020, p. 48).

A more detailed analysis of the data covering the level of trust in banks in individual countries reveals that between 2007 and 2010, the greatest fall in trust occurred in the United States from $71 \%$ to $25 \%$, the United Kingdom from $46 \%$ to $16 \%$, Germany from $44 \%$ to $23 \%$ and Ireland from $26 \%$ to $6 \%$. In the same period, significant increases in trust, or high trust values, were recorded in China - an increase of 12 p.p. to 90\%, India - an increase of 4 p.p. to $87 \%$, Japan - an increase of 10 p.p. to $71 \%$ and Brazil - an increase of 21 p.p. to $69 \%$ (Edelman, 2011, p. 16).

The most recent data presenting trust in the banking sector in selected countries of the world among the general population (Edelman, 2019, p. 35) indicate a fairly clear division into Western culture countries with a moderate or low level of trust: Italy 36\%, Australia 40\%, Ireland 40\%, Spain 42\%, France 45\%, United Kingdom 55\%, USA 62\%, and countries (mainly Asian) with above-average or high levels of public trust in the sector: China 94\%, India 87\%, Indonesia 86\%, Singapore 83\%, Hong Kong 81\%, South Africa 71\%, Mexico 71\%. In the opinion of the author, the above differences in the level of trust are most likely influenced by cultural factors. Eastern culture in general is more collective and trusts state/corporate institutions, whereas Western culture is more individual and skeptical to such entities.

Since mid-2010s, the Edelman reports ceased to separate the category of banks (with the exception of the 2019 report mentioned above), replacing it with the category of financial services. Originally, financial services included banks, insurance companies and financial advisory/asset management. In recent years, the scope of research also included credit cards, mobile wallets, digital wealth management and cryptocurrencies. It is worth pointing out, however, that in 2013 and 2018 (detailed data are available only for these periods) banks enjoyed the highest trust of respondents within the financial services sector.

The data contained in table 1 demonstrate that the growing level of trust in financial services in recent years has been accompanied by an invariably significant difference in ratings between respondents classified as the informed public and mass population. A deeper analysis of the data indicates that also in this category there is a geographical dispersion of research results. In the countries of the Western civilisation there are large differences in the level of trust between both groups of respondents, for example the United Kingdom - 18 percentage points, the United States - 12 percentage points, while in the countries of the Eastern civilisation, Japan and China, the differences are 4 and 2 percentage points, respectively. The presented results form the basis for a rec- 
ommendation addressed to the boards of banks operating in Western countries to take more extensive actions with respect to mass population customers. This group of customers is important from the point of view of business profitability and the level of trust in banks due to its size or percentage share in the societies of individual countries.

A relatively high level of trust in banks was recorded in surveys conducted in 2017 and 2018 (table 1). The percentage of respondents from the general population trusting banks in these years was $60 \%$ and $62 \%$, respectively. These values were similar to those observed in 2006, as it must be borne in mind that the results obtained among the informed public are usually higher than those obtained among the general population. The data presented in the EY $(2014$, p. 8) report prove helpful in identifying the factors contributing to such a high level of trust in banks. Bank customers indicated the most important factors increasing trust in banks: financial stability, appropriate customer treatment, appropriate security procedures relating to the protection of financial and personal data, as well as efficient problem-solving/complaint handling. In the Edelman (2019, p. 28) report, the respondents pointed to the following factors as the most important in increasing trust in financial services companies: easily found product/service information, easily understood terms/conditions, and reliable fraud protection. Therefore, it can be assumed that the analysed increase in trust in banks was influenced by the positive situation in the global economy which determines the stability of banks, or more broadly the financial systems, the improvement of the quality of banking services, including customers perception of banks' care for security.

\section{Trust in the banking sector in Poland}

According to the author, the analysis of Poles' trust in banks should be preceded by a scrutiny of the level of trust of the country's citizens in various types of institutions. This will allow us to understand what type of society Poles are, whether they are trusting or rather the opposite. The Edelman (2013, p. 6) report presents the aggregated level of Poles' trust in institutions such as the government, NGOs, business, and media. The Trust Index value measured for Poland in 2010 was 49 points on a scale from 1 to 100, in 2011 it was 44 points, while in 2012 it was 48 points. In all cases the values were so low that Poles were placed in the group of 'distrusters'. It is worth noting that in 2012, data obtained from the general population surveys were also provided. The trust of the Polish society in institutions was down to 34 points, which was the third lowest score among 26 surveyed countries. Moreover, the difference of 14 points in the level of trust between respondents classified as the informed public and the general population was the biggest among the analysed countries. In 2017 the Trust Index for Poland reached 39 points (Edelman, 2019, p. 5). At that time, leaders in terms of public trust could boast the following values: China (74), Indonesia (71), India (68) and the United Arab Emirates (74). However, these values were 
lower than those obtained for the same countries in 2014: China (75), Indonesia (78), India (79) and the United Arab Emirates (84) (Edelman, 2015, p. 6). This may indicate a serious crisis of social trust in institutions that is currently affecting our civilisation.

The analysis of the data contained in table 1 shows that in the periods when detailed data covering Poland were available, the level of trust in business institutions in the informed public group was 44-48\%, except for the years 2012 and 2015 , where the level of trust increased to $56 \%$ and $52 \%$, respectively. This does not change the fact that in all the years the level of trust of the representatives of Polish society was below the average values usually calculated for about 25-28 countries classified among the leading world economies. As predicted, the trust of the general Polish society in business turned out lower than that declared by the informed public. The percentage of respondents of the general population trusting businesses in 2014 was only 36\%, while in 2015 it was not much more $-38 \%$.

Only one Edelman (2013, p. 22) report provides values on Poles' trust in banks. In 2007-2012, the level of trust in banks among Poles aged 35-64 included in the informed public dropped from $63 \%$ to $44 \%$ and this was one of the biggest drops in trust in the world recorded during the 5 years mentioned above. Higher or similar decreases occurred in Spain (-26 p.p.), the UK and the Netherlands (-25 p.p.), Iceland (-24 p.p.), the United States $(-20$ p.p.) and Germany (-19 p.p.).

Chart 1 presents the results of research on the reputation (image) of the Polish banking sector which have been carried out on behalf of the ZBP since 2007. The survey was conducted using the CAPI method on a representative sample of Poles aged 15 and over, from March to April of the year in which the report was published.

Theoretically, the changes in the level of trust in banks in Poland correspond to the trends observed in this respect on a global scale. However, a more detailed analysis of the data allows us to see the specificity of the Polish market. In the years 2007-2008, no particular enthusiasm could be observed in the level of trust in banks, even though it was a time of high economic growth and a significant increase in lending. At the end of the first quarter of 2008, when the survey was conducted, the majority of the society was not aware of the scale of the global banking crisis that was gaining in strength, hence only a slight change in the level of trust compared to 2007. In turn, in 2009 there was a huge drop in trust in the Polish banking sector. Such a significant reduction was greatly affected by worrying information from around the world that the banking crisis had turned into a global financial crisis. This raised fears in the society about the financial condition of banks operating in Poland and their potential bankruptcy. Sources of reduction of trust can also be sought in the dissatisfaction of those who had placed their savings in investment funds through banks, as well as those who had taken out foreign currency loans. In the author's opinion, another important factor was the time of the research. 
It was carried out shortly after the wave of sell-offs on the stock and currency markets which took place in January and February 2009. In the following years, social trust in the banking sector in Poland was restored. The process was slow, even though there were no bank bankruptcies in the first years of the crisis and the financial health of commercial banks in the 2010s may be rated as good at the least. This should be related to the emergence of phenomena unfavourable from the point of view of the sector, such as: the Amber Gold scandal, the GetBack scandal, problems of bank customers related to insurance policies combined with deposits and foreign currency loans, bankruptcies of cooperative savings and credit unions and cooperative banks, a negative image campaign on the part of the government and public media preceding the introduction of the 'bank tax'. The ZBP $(2019$, p. 3) report shows that in 2019, trust in banks in Poland rose sharply and reached a record level of $72 \%$. Equally optimistic information is contained in the CBOS (2018, pp. 3-4) opinion poll centre report. In the fourth quarter of 2018, banks were trusted by $74 \%$ of adult representatives of Polish society. In turn, a KPMG \& ZBP (2019, pp. 10-15) report shows that banks were more trusted by Poles than Google, Facebook, Apple, cooperative banks, telecommunication companies, cooperative savings and credit unions, other technology companies, and loan companies. Moreover, $76 \%$ of the respondents indicated banks as institutions whose financial services they would choose. For comparison, the second highest score was achieved by Google with $27 \%$ and the third highest by telecommunication companies with $21 \%$. In the aforementioned survey, the respondents most often indicated banks as institutions to which they would entrust their money (78\%), as institutions which are convenient to use (73\%), and as institutions which are considered safe $(72 \%)$. The high level of security provided by banks is also indicated by the results of the ZBP (2020, p. 9) report. For 59\% of the Poles surveyed, banks are leaders in security, ahead of the army and police (40\%), government institutions (31\%) and technology companies (22\%). In another KPMG (2019, p. 4) report, as many as $90 \%$ of Poles expressed the belief that the bank to which their remuneration goes uses appropriate technologies to ensure the security of funds.

The results of the research presented so far clearly show that banks have managed to create in the Polish society an image of institutions that care about security. The results of the research presented further in this paper indicate that ensuring security is one of the key factors in increasing trust in banks. Other reasons behind increased trust in banks indicated by respondents are: customer care/friendly, professional service, and market stabilisation. On the other hand, the most frequently signaled reasons upsetting trust in banks included: unfair practices of banks, lack of security/stability, and scandals in banks and institutions from the sector (ZBP, 2018, p. 4; 2019, p. 4).

In the opinion of the author, the other factor, apart from ensuring security, influencing the high level of public trust in banks was the stability of the market. In the period preceding the research, i.e. at the end of 2018, the Polish economy was in good shape, the financial situation of the banking sector was similarly 
positive, whereas no signals worrying the society were coming from the financial market.

The last determinant of the increase in trust in banks was the improvement in the quality of customer service. This conclusion is based on the data from the reports of the ZBP indicating a continuous increase in customers' trust in their own bank. Moreover, this trust has always been higher than in relation to the whole banking sector in Poland. This may mean that respondents who were bank customers were having more and more positive experiences of cooperation with these institutions and translated their satisfaction into trust in the whole sector. Equally important are the data indicating a significant increase in customer trust in the bank employees who usually serve them. In 2012, 47\% of customers trusted bank employees (ZBP, 2013, p. 5), while in 2019 this share increased to 83\% (ZBP, 2019, p. 3). The impact of increased customer trust in banks and the banking sector is significant as at least four out of the six determinants of trust in banks identified by van Esterik-Plasmeijer \& van Raaij (2017) relate directly to employees of these institutions. Moreover, in the opinion of bank customers, contacts with bank staff, in addition to their own experience, are the most important sources of information when rating their trust in these institutions (ZBP, 2016, p. 10).

\section{Conclusion}

The results of international research indicate that in these times of crisis of social trust in institutions, trust in banks is increasing. The reasons for this phenomenon can be found in the actions taken by banks to improve the quality of customer service, ensure the security of financial and personal data, and maintain the stability of the sector. The paper recognises the geographical and cultural differences of trust in the sector worldwide. In the countries of the Western civilisation, the level of respondents' trust in banks is lower and more diverse depending on the status of the respondent. Trust in banks is much higher in the countries of the Eastern civilisation. With this in mind, a challenge for banks, especially those operating in Western civilisation countries, is to increase the level of social trust, which should be accompanied by the reduction of differences in the level of trust in these institutions observed within individual societies.

The changes in the level of trust recorded for the Polish market were to a large extent a reflection of processes taking place on a global scale. However, a more detailed analysis of the data showed that during the financial crisis in 2009, the decline in the level of trust in banks observed in Poland was stronger than on the global market. In turn, during the period of global economy growth, one year before the outbreak of the COVID-19 pandemic, trust in the banking sector in Poland was at a higher level than the average level of trust in banks recorded on a global scale. Such a considerable dispersion of results stems mainly from factors of an emotional nature. The global financial crisis raised concerns 
about the stability of the banking system in Poland, despite the lack of internal rationale in this market. On the other hand, the high ratings in the studies conducted in recent years may have been influenced by a strong sense of financial stability, strengthened by the propaganda message of the government-dependent public media, showing the Polish economy as a leader in terms of development on a European or even global scale.

High trust in the banking sector in Poland, higher by about 10-12 p.p. (depending on the survey) than the average value for 26 countries obtained in international surveys carried out in the same period, is particularly surprising in the situation of a permanent crisis of trust in institutions among Poles and media attempts to discredit these institutions. According to the author, this situation results not only from the stability of the system, but also from the fact that trust in banks in Poland is built on the basis of the competence of their employees and the image of banks as institutions that use new technologies to provide comfort and security to their customers. The factors lowering the level of trust in banks in Poland, such as unfair bank practices and scandals in banks and institutions from the sector, which were indicated in other studies, do not, in the opinion of the author, translate into a significant reduction in trust in banks. This can be explained by the relatively small percentage of people who have had bad experiences of dealing with banks (ZBP, 2016, p. 16).

\section{References}

Acharya, V.V. (2009). A theory of systemic risk and design of prudential bank regulation. Journal of Financial Stability, 5(3). doi:10.1016/j.jfs.2009.02.001.

Bordo, M.D. (2008). An historical perspective on the crisis of 2007-2008. NBER Working Paper, 14569. doi:10.3386/w14569.

CBOS. (2018). Zaufanie do sektora bankowego. Retrieved 23.01.2020 from https://www.cbos.pl.

Cohn, A., Fehr, E., \& Maréchal, M.A. (2014). Business culture and dishonesty in the banking industry. Nature, 516. doi:10.1038/naturel3977.

Dąbrowski, T.J. (2017). Współczesny bank: między instytucją zaufania publicznego a przedsiębiorstwem. Bezpieczny Bank, 1(66).

Dziawgo, L. (2009). Status instytucji zaufania publicznego we współczesnej bankowości: pomiędzy partnership banking a killer banking. Ekonomiczne Problemy Ustug, 38.

Dziawgo, L. (2011). Współczesny biznes bankowy: patologiczne otoczenie „ekonomia polityczna” oraz ład monetarno-instytucjonalny rynku finansowego jako zagrożenie dla bankowości. Bezpieczny Bank, 3(45).

Edelman. (2007-2020). Trust barometer 2007-2020. Retrieved 20.01.2020 from https://www.edelman.com.

Ennew, C., \& Sekhon, H.S. (2007). Measuring trust in financial services: the trust index. Consumer Policy Review, 17(2). 
EY. (2014). W centrum uwagi: doświadczenia klienta $w$ kontakcie z marką: światowe badanie klientów banków detalicznych 2014. Retrieved 25.01.2020 from https://www.ey.com.

Gangl, K., Kastlunger, B., Kirchler, E., \& Voracek, M. (2012). Confidence in the economy in times of crisis: social representations of experts and laypeople. Journal of Socio-Economics, 41(5). doi:10.1016/j.socec.2012.05.018.

Goodfriend, M. (2011). Money markets. Annual Review of Financial Economics, 3(1). doi:10.1146/annurev-financial-102710-144853.

Gradoń, W. (2015). Czy banki nadal są instytucjami zaufania publicznego. Annales Universitatis Mariae Curie-Sktodowska: Sectio H: Oeconomia, 48(4). doi:10.17951/h.2014.48.4.61.

Haldane, A.G., \& May, R.M. (2011). Systemic risk in banking ecosystems. Nature, 469. doi:10.1038/nature09659.

Idzik, M., \& Gieorgica, J. (2019). Reputacja sektora bankowego w Polsce: wnioski z badania w 2019 roku. Bezpieczny Bank, 3(76). doi:10.26354/ bb.4.3.76.2019.

Jongchul, K. (2013). Modern politics as a trust scheme and its relevance to modern banking. Journal of Economic Issues, 47(4). doi:10.2753/ jei0021-3624470401.

KPMG \& ZBP. (2019). PSD2 i open banking: rewolucja czy ewolucja. Retrieved 24.01.2020 from https://home.kpmg.

KPMG. (2019). Czy klient jest najważniejszy: na bank: analiza doświadczeń klienckich oferowanych przez banki w Polsce. Retrieved 24.01.2020 from https:// home.kpmg.

Laeven, L. (2011). Banking crises: a review. Annual Review of Financial Economics, 3(1). doi:10.1146/annurev-financial-102710-144816.

Langley, P. (2013). Anticipating uncertainty, reviving risk: on the stress testing of finance in crisis. Economy and Society, 42(1). doi:10.1080/03085147.2012 .686719 .

Lastra, R.M., \& Wood, G. (2010). The crisis of 2007-09: nature, causes, and reactions. Journal of International Economic Law, 13(3). doi:10.1093/jiel/ jgq022.

Lynch, J.J. (1991). Ethical banking: surviving in an age of default. London: Macmillan.

Nishimura, K.G. (2010). Financial system stability and market confidence. Asian Economic Papers, 9(1). doi:10.1162/asep.2010.9.1.25.

Polillo, S. (2011). Money, moral authority, and the politics of creditworthiness. American Sociological Review, 76(3). doi:10.1177/0003122411407737.

Reynolds, J.N., \& Newell, E. (2011). Ethics in investment banking. New York: Palgrave Macmillan.

Sako, M. (1992). Prices, quality and trust: inter-firm relations in Britain and Japan. Cambridge: Cambridge University Press.

Schumpeter, J.A. (1939). Business cycles: a theoretical, historical and statistical analysis of the capitalist process. New York: MacGraw-Hill. 
Szambelańczyk, J. (2010). Stabilność systemu bankowego a paradygmat bankowości. Finanse, 1(2).

Sztompka, P. (2007). Zaufanie: fundament spoteczeństwa. Kraków: Znak.

van Esterik-Plasmeijer, P.W.J., \& van Raaij, W.F. (2017). Banking system trust, bank trust, and bank loyalty. International Journal of Bank Marketing, 35(1). doi:10.1108/IJBM-12-2015-0195.

van Raaij, W.F. (2016). Understanding consumer financial behavior: money management in an age of financial illiteracy. New York: Palgrave Macmillan.

Whitener, E.M., Brodt, S.E., Korsgaard, M.A., \& Werner, J.M. (1998). Managers as initiators of trust: an exchange relationship framework for understanding managerial trustworthy behavior. Academy of Management Review, 23(3).

Wicker, E. (2000). Banking panics of the gilded age. Cambridge: Cambridge University Press. doi:10.1017/cbo9780511571992.

ZBP. (2013). Wizerunek polskiego sektora bankowego: edycja 2013. Retrieved 27.12.2019 from https://zbp.pl.

ZBP. (2016). Reputacja polskiego sektora bankowego 2016. Retrieved 27.12.2019 from https://zbp.pl.

ZBP. (2018). Gtówne obserwacje z wyników badań reputacji polskiego sektora bankowego: edycja 2018. Retrieved 27.12.2019 from https://zbp.pl.

ZBP. (2019). Wybrane obserwacje w zakresie oceny reputacji i zaufania do banków w Polsce w 2019 r. Retrieved 27.12.2019 from https: / /docplayer.pl.

ZBP. (2020). Cyberbezpieczny portfel. Retrieved 25.02.2020 from https://www. zbp.pl.

\section{Acknowledgements}

Author contributions: author has given an approval to the final version of the article.

Funding: this research was funded by the Nicolaus Copernicus University in Torun, Faculty of Economic Sciences and Management statutory sources. 


\section{Appendix}

Table 1.

Trust in institutions in 2006-2018 (in \%)

\begin{tabular}{|c|c|c|c|c|c|}
\hline \multirow{3}{*}{ Year } & \multicolumn{4}{|c|}{ Global scale } & \multirow{3}{*}{$\begin{array}{c}\text { Poland } \\
\text { business } \\
\text { informed public }\end{array}$} \\
\hline & \multirow{2}{*}{$\begin{array}{c}\text { banks } \\
\text { informed public }\end{array}$} & \multicolumn{2}{|c|}{ financial institutions } & \multirow{2}{*}{$\begin{array}{c}\text { business } \\
\text { informed public }\end{array}$} & \\
\hline & & mass population & informed public & & \\
\hline 2006 & 68.0 & - & - & 52.0 & - \\
\hline 2007 & 56.0 & - & - & 51.0 & 45.0 \\
\hline 2008 & 45.0 & - & - & 50.0 & 47.0 \\
\hline 2009 & 48.0 & - & - & 59.0 & - \\
\hline 2010 & 50.0 & - & - & 56.0 & 44.0 \\
\hline 2011 & 47.0 & 44.0 & 49.0 & 53.0 & 46.0 \\
\hline 2012 & 50.0 & 47.0 & 52.0 & 58.0 & 56.0 \\
\hline 2013 & 54.0 & 49.0 & 54.0 & 59.0 & 45.0 \\
\hline 2014 & 55.0 & 48.0 & 55.0 & 57.0 & $48.0\left(36.0^{*}\right)$ \\
\hline 2015 & - & 51.0 & 60.0 & 63.0 & $52.0\left(38.0^{*}\right)$ \\
\hline 2016 & - & 53.0 & 65.0 & 65.0 & - \\
\hline 2017 & $60.0^{*}$ & 52.0 & 61.0 & 64.0 & - \\
\hline 2018 & $62.0^{*}$ & 55.0 & 67.0 & 68.0 & - \\
\hline
\end{tabular}

Notes:

* data presented for general population.

Source: Own preparation based on Edelman (2007-2019).

\section{Chart 1.}

Trust in banking sector in Poland in 2007-2019 (in\%)

80

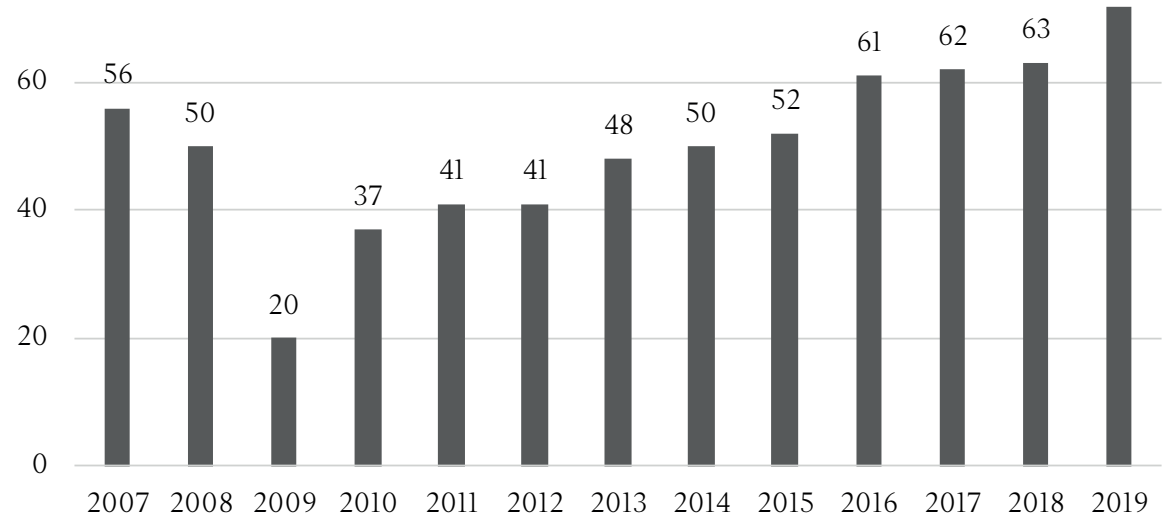

Source: Idzik \& Gieorgica (2019). 